\title{
The Impact of Customer Service of Mexican Companies Based on Customer Care
}

\author{
José G Vargas Hernández* and Edgar José Gálvez Moreno* \\ ${ }^{1}$ Research Professor of the Administration Department, University Center for Economic and Managerial Sciences \& University of Guadalajara, México \\ ${ }^{2}$ Autonomous University of Sinaloa, Mexico
}

Submission: January 01, 2018; Published: July 16, 2018

"Corresponding author: José G Vargas-Hernández, University of Guadalajara, Research Professor of the Administration Department, University Center for Economic and Managerial Sciences, Mexico, Tel: +52 331545 2587; Email: Josevargas@cucea.udg.mx

Edgar José Gálvez Moreno, Autonomous University of Sinaloa North Zone, Los Mochis Prol. Ángel Flores and Social Justice s / n Col. Sinaloa, Mexico, Tel: +52 331545 2587; Email: Edgarjgm94@gmail.com

\begin{abstract}
The purpose of this research is to measure the level of customer service of Mexican companies in terms of customer service, considering that customer service is directly related to offer a good customer service. This research is analytical and descriptive, because it contains the main concepts about research, as well as the main authors and creators of the same and descriptive because in the research are tables and tables that help explain in a way Easier for the correct compression and differentiation of these concepts. With this research they will understand the importance and difference between a service and an attention, and once understood this will be able to better train their staff to obtain better and greater results in their companies and reflected in their profits.
\end{abstract}

Keywords: Customer service, Customer Support, Companies and JEL: M12, M21, M31

\section{Introduction}

The main purpose of organizations is to ensure that their main corporate activities create and add value over time, efficiently and effectively [1]. In this sense, good treatment towards clients can be the key to success to remain positioned in the market. Having stability allows the business to cultivate motivation for employees, helping us to have less turnover of staff. This is very important since it does not create demotivation among them. This research is analytical and descriptive, because it contains the main concepts about the research, as well as the main authors and creators of the same. It is descriptive because in the research there are tables that help to explain in a certain and simpler way for the correct compression and differentiation of these concepts. In view of the results and recommendations of this scientific research, small and medium entrepreneurs in Mexico should urgently consider what is proposed here, since with it they will be able to provide a better service to their users, and a better service to their clients, which they found throughout this investigation.

\section{Background of the Problem}

Some users and consumers complain about customer service in companies that have the need to offer a face-to-face service with the user, such as supermarkets, automotive agencies or a bank branch, etc. The problem has always existed, but unfortunately Mexican companies do not care about providing quality customer service, if not all they are interested in is selling, without taking into account if that customer was satisfied with their product or with the attention offered by an advisor. This is where the problems arise, when the client complains but does not go beyond a simple complaint. In this type of situation, one of the main problems of Mexicans is that they do not know how to complain or demand their rights when they are given bad service. Godoy mentions that today, customer service is an activity developed by organizations oriented to satisfy the needs of their customers; achieving thus increase their productivity and be competitive. The client is the main protagonist and the most important factor in the business game [2].

\section{Delimitation of the Problem}

The present investigation will be applied to the Mexican companies that grant a direct service with the client, like a supermarket, automotive agency or some bank. The approach that is intended to provide this research has to do with the factors that are important for customer service such as: attention, empathy and service attitude. The main limitation is that sometimes employees give bad customer service due to several factors. The main one is the lack of constant training and the low salaries they receive. However, they are behaviors that must change immediately since modern consumers demand a change and a good service, since they are paying for it. It is in this sense that González mentions that a common problem detected in all 
sectors is that, although there are high productivity equipment or new production processes in the market that use the most modern technologies, the small size of these companies prevents them from accessing them [3]. On the one hand, the investment is too large and on the other, the production capacity of these equipment exceeds the needs of the company. Taking into consideration the problems, the following research questions are required:

a) What is the level of customer service of Mexican companies based on customer service?

b) What is the level of customer service of Mexican companies based on reliability?

c) What is the level of customer service of Mexican companies according to capacity?

d) What is the level of customer service of Mexican companies based on empathy?

\section{Justification}

Companies depend on their customers. The good treatment of customers is the key to success to remain positioned in the market. Having stability allows the business to cultivate motivation for employees, helping it to have less turnover of staff. This is very important since it does not create demotivation among them, encouraging them to do things right the first time, and therefore always providing a service or quality care.

\section{Research Variables and Hypotheses}

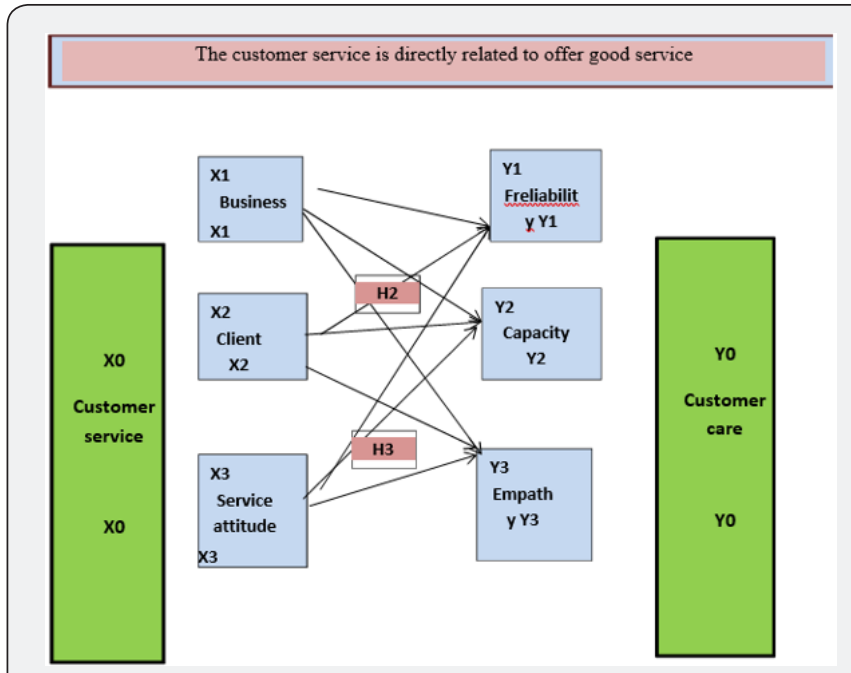

Figure 1: Anti-HIV testing strategy of pooled sera using enzyme immuno assay [1].
a) Independent variable $(\mathrm{X})=$ Customer service

b) Dependent variable $(\mathrm{Y})=$ Customer service

i. General Hypothesis: The customer service is directly related to offer good customer service.

ii. Specific Hypotheses: ss

Table 1: Description of research variables, dimensions and indicators.

\begin{tabular}{|c|c|c|c|}
\hline Variable & Description & Dimensions & Indicators \\
\hline \multirow{2}{*}{ X0 } & \multirow{3}{*}{$\begin{array}{l}\text { Activity of interrelation offered by a supplier for the purpose of a customer } \\
\text { obtaining a product or service, both at the time and in the right place and } \\
\text { where it ensures a correct use of it (Agudelo, 2013, pp. 17-22) [4]. }\end{array}$} & Company & Customer retention \\
\hline & & Client & Buyer satisfaction \\
\hline Customer Service & & Service attitude & $\begin{array}{l}\text { Customer loyalty } \\
\text { Customer rating } \\
\text { Accessible simple }\end{array}$ \\
\hline Y0 & \multirow{6}{*}{$\begin{array}{l}\text { It is an activity developed by organizations oriented to satisfy the needs } \\
\text { of their clients, thus increasing their productivity and being competitive } \\
\text { (Godoy N.,2011, pgs. 23-35) [2]. }\end{array}$} & Reliability & $\begin{array}{l}\text { Serviceability } \\
\text { Fulfill times }\end{array}$ \\
\hline \multirow{5}{*}{ Customer Care } & & \multirow{2}{*}{ Capacity } & Willingness to help \\
\hline & & & Efficiency \\
\hline & & \multirow{3}{*}{ Empathy } & \\
\hline & & & Goof treatment \\
\hline & & & kindness \\
\hline
\end{tabular}

\section{$H_{1}=X_{1}+X_{2}+X_{3} \rightarrow Y_{1}$}

The company, the customer and the service attitude are directly related to reliability.

$H_{2}=X_{1}+X_{2}+X_{3} \rightarrow Y_{2}$

The company, the client and the service attitude are directly related to the capacity.

$$
H_{3}=X_{1}+X_{2}+X_{3} \rightarrow Y_{3}
$$

The company, the client and the service attitude are directly related to empathy (Table 1, Figure 1). Therefore, the hypothesis of this research is that customer service is directly related to offer good customer service. This data will be split to develop in a more in-depth way what is a service and care like as their differentiation between these concepts, considering that the objective is to measure the level of customer service of Mexican companies based on customer care.

\section{Research Objectives}

a) General objective: Measure the level of customer service of Mexican companies based on customer care.

b) Specific objectives: 
i. Measure the level of customer service of Mexican companies based on reliability.

ii. Measure the level of customer service of Mexican companies according to capacity.

iii. Measure the level of customer service of Mexican companies based on empathy (Table 2).

Table 2: Congruence matrix.

\begin{tabular}{|c|c|c|c|}
\hline General Questions & Specific Questions & General Objective & Specific Objective \\
\hline & $\begin{array}{l}\text { What is the level of customer service of Mexican } \\
\text { companies based on customer care? }\end{array}$ & & $\begin{array}{c}\text { Measure the level of customer } \\
\text { service of Mexican companies in } \\
\text { Reliability function }\end{array}$ \\
\hline \multirow{3}{*}{$\begin{array}{l}\text { Is customer service } \\
\text { directly related } \\
\text { to providing good } \\
\text { customer care? }\end{array}$} & $\begin{array}{l}\text { What is the level of customer service of Mexican } \\
\text { companies based on reliability? }\end{array}$ & \multirow{3}{*}{$\begin{array}{l}\text { Measure the level of } \\
\text { customer service of Mexican } \\
\text { companies in customer } \\
\text { service function. }\end{array}$} & $\begin{array}{l}\text { Measure the level of customer } \\
\text { service of Mexican companies in } \\
\text { customer service function. }\end{array}$ \\
\hline & $\begin{array}{l}\text { What is the level of customer service of Mexican } \\
\text { companies according to capacity? }\end{array}$ & & \multirow{2}{*}{$\begin{array}{l}\text { Measure the level of customer } \\
\text { service of Mexican companies in } \\
\text { function of empathy. }\end{array}$} \\
\hline & $\begin{array}{l}\text { What is the level of customer service of Mexican } \\
\text { companies based on the empathy? }\end{array}$ & & \\
\hline
\end{tabular}

\section{Conceptual Theoretical Framework}

\section{Customer service}

To define the variables of this research, it is first necessary to begin by defining certain concepts that are basic, but necessary to better understand what is being investigated. First, it begins by defining what is a service, followed by what is a customer, to later understand that it is "customer service". Stanton defines services as identifiable and intangible activities that are the main purpose of a transaction designed to provide customers with satisfaction of wants or needs [5]. Services are activities, benefits or satisfactions that are offered for rent or sale, and which are essentially intangible and do not result in the ownership of something [6]. A service is the result of the application of human or mechanical efforts to people or objects. Services refer to a fact, performance or effort that is not physically possible [7]. The Association [8] mentions that services (according to one of the two definitions they provide) are products, such as a bank loan or the security of a domicile, that are intangible or at least substantially, if they are totally intangible, they are exchanged directly from the producer to the user, cannot be transported or stored, and are almost immediately perishable. Service products are often difficult to identify, because they come into existence at the same time they are purchased and consumed. They cover the intangible elements that are inseparability; which usually involve the participation of the client in a certain important way. They cannot be sold in the sense of the transfer of ownership; and they do not have any title. Today, however, most products are partly tangible and partly intangible, and the dominant form is used to classify them as goods or services (all are products). These common, hybrid forms may or may not have the qualities given for totally intangible services. Kotler explains that a service is a work, an accomplishment or an act that is essentially intangible and does not necessarily result in ownership of something [9]. Its creation may or may not be related to a physical product. Complementing this definition, it should be noted that according to the mentioned authors, the services cover a wide range, ranging from renting a hotel room, depositing money in a bank, traveling by plane to visiting a psychiatrist, up to cut the hair, watch a movie or get advice from a lawyer. Many services are intangible, in the sense that they do not include almost any physical element, such as the task of the management consultant, but others may have a physical component, such as fast foods.

\section{Client}

The customer is the potential or actual buyer of the products or services. The customer is a person or company that acquires goods or services, not necessarily the final Consumer [10]". According to the Marketing Dictionary the customer is a term that defines the person or organization that makes a purchase, may be buying on their behalf, and personally enjoy the acquired good, or buy for another, such as in the case of children's articles, it is the most important part of the company's population [11]. Barquero mentions that the word client comes from ancient Greek and refers to the person who depends on [12]. Customers are those people who have a certain need for a product or service that my company can satisfy. Kotler mentions some recommendations about what is most valuable in any company. The products come and go [13]. The challenge for companies is focused on making their customers last longer than their products. They have to consider more the concepts life cycle of the market and life cycle of the client instead of the product life cycle concept. Companies must consider their clients as an asset that must be managed like any other asset of the company. If they do not lend attention to their customers, some other company will do it.

\section{Customer service}

Customer service considers it as all the activities that unite an organization with its clients [14]. In this definition, it is emphasized that customer service is a range of activities that together create a relationship. It can also be considered as the secondary activities carried out by a company to optimize the satisfaction that the client receives from its main activities. The customer service can be broken down into three phases: presale, sale and after-sales. Studying and defining each one of them allows to identify the orientation that the activities should have at each moment of the consumer's buying cycle [15]. According 
to the author, the pre-sale customer service consists in offering the potential customer the products he wants, the best qualities, the most pleasant and clear presentation and the best possible price. The activity in the sale stage is based on providing all possible information about the product sold, way of use, medium for support and maintenance or other aspects such as the delivery mode of the product. In post-sales, it concentrates on the application of actions to allow the customer to be satisfied with the product, even better proud of its purchase, motivated to buy back, enabled to make easily any guarantee, exchange by default and find the precise technical support.

\section{Customer service}

Let's start by defining what is the attention to easily understand what customer service is. Attention: Kahmeman explains that the concept of attention implies the existence of a control by the organism, of the choice of the stimuli that, in turn, will control its conduit, being the attention something more than a mere selection, which is also related to quantity or intensity [16]. The author considers that both the voluntary and the involuntary selection must take into account the intensive aspects of care. Prieto mentions that customer service is the set of activities developed by market-oriented organizations, aimed at identifying the needs of customers in the purchase to satisfy them, thus achieving to meet their expectations, and therefore, create or increase the satisfaction of our customers [17]. To carry out a successful customer service policy, the company must have sources of information about a target market and the behavior of its consumers. The fact of knowing the origins and needs of these expectations will, subsequently, convert them into demand. To determine this, periodic surveys should be conducted to identify the possible services that will be offered and determine the strategies and techniques that may be used. Customer service is the set of benefits that the customer expects as a result of the image, price and reputation of the product or service it receives [18].

\section{Theory of motivation-hygiene by Frederick Herzberg}

The psychologist Frederick Herzberg proposed the theory of motivation-hygiene. In the belief that the relationship of an individual with his work is basic, and that his attitude towards this work may well determine the success or failure of the individual, Herzberg investigated the question What do people want from their position? He asked people to describe in detail situations where he felt exceptionally well and badly in his position. According to Herzberg, the factors that lead to job satisfaction are separate and distinct from those that lead to job dissatisfaction. Therefore, administrators who seek to eliminate factors that create dissatisfaction in the position can bring peace, but not necessarily motivation. They will be appeasing their work force, instead of motivating it.

As a result, Herzberg has indicated that characteristics such as company policies and administration, supervision, interpersonal relationships, working conditions and salaries can be conceptualized as hygiene factors. When they are adequate, people will not be dissatisfied; however, neither will be satisfied. If wanted to motivate people in their position, Herzberg suggests emphasizing achievements, recognition, work itself, responsibility and growth [19].

\section{The classical theory of administration Henry Fayol}

His studies covered all areas of the company, since it was very important for Fayol both to sell and produce, to finance himself and to secure the assets of a company. In short, the organization and its components were considered as a large interdependent system, as internal customers. Fayol, in his functional and systemic analysis of the organizations, found certain operations that were repeated in any type of companies, which were necessary for the achievement of their objectives. Later, this study translated into a deeper analysis regarding the division of labor within current organizations. For Fayol, administration is a common activity for any type of business, for-profit and nonprofit organizations, political, sports, religious or entertainment organizations, etc., and it plays a very important role in society. Every company needs to apply a methodology in its actions, and the administrative process is undoubtedly that methodology that is required for the solution of the problems that arise in any organization [20].

Table 3: Theories of customer service.

\begin{tabular}{|c|c|c|}
\hline Theory & Author & Principles \\
\hline $\begin{array}{l}\text { Theory of Motivation Hygiene by } \\
\text { Frederick Herzberg }\end{array}$ & Frederick Herzberg & $\begin{array}{l}\text { In the belief that the relationship of an individual with his work is basic, and that } \\
\text { his attitude towards this work may well determine the success or failure of the } \\
\text { individual, Herzberg has indicated that characteristics such as the policies and } \\
\text { the administration of the company, the supervision, the interpersonal relations, } \\
\text { the working conditions and the salaries can be conceptualized as factors of } \\
\text { hygiene. When they are adequate, people will not be dissatisfied; however, } \\
\text { neither will be satisfied (Herzberg, 1968) [19]. }\end{array}$ \\
\hline \multirow[t]{2}{*}{ Classic Theory of Administration } & Henry Fayol & $\begin{array}{l}\text { For Fayol, it was very important to sell and produce, to finance and to secure } \\
\text { the assets of a company. In short, the organization and its components were } \\
\text { considered as a large interdependent system, as internal customers. }\end{array}$ \\
\hline & & $\begin{array}{l}\text { Every company needs to apply a methodology in its actions, and the } \\
\text { administrative process is undoubtedly that methodology that is required for the } \\
\text { solution of the problems that arise in any organization Fayol [20]. }\end{array}$ \\
\hline
\end{tabular}




\begin{tabular}{|c|c|c|}
\hline The Theory X and The Theory Y & $\begin{array}{c}\text { Theory X: It is based on the old model of threats and the presumption of } \\
\text { mediocrity of the masses. It is assumed that individuals have a natural tendency } \\
\text { to leisure and that work is a form of punishment McGregor [21]. }\end{array}$ \\
\cline { 2 - 3 } $\begin{array}{c}\text { Douglas Murray } \\
\text { Mcgregor }\end{array}$ & $\begin{array}{c}\text { Theory Y: Considers that their subordinates find in their employment a source } \\
\text { of satisfaction and that they will always strive to achieve the best results for the } \\
\text { organization, thus, companies must release the skills of its workers in favor of } \\
\text { these results McGregor [21]. }\end{array}$ \\
\hline
\end{tabular}

\section{The theory $x$ and the theory and of Douglas Murray Mcgregor}

The theory $\mathrm{X}$ is based on the old model of threats and the presumption of mediocrity of the masses. It is assumed that individuals have a natural tendency to leisure and that work is a form of punishment, which presents two urgent needs for the organization: supervision and motivation [21]. The managers of Theory $\mathrm{Y}$ consider that their subordinates find in their employment a source of satisfaction and that they will always strive to achieve the best results for the organization, thus, companies must release the skills of their workers in favor of said results. The theory that has relation with the investigation is the classic theory of the Administration Henry Fayol, since it deepened in the excellence of the companies generating utilities to the company, as well as the creation of tools or processes to carry out the correct function of the company [21] (Table 3).

\section{Theory of Taylor administration}

Before Taylor's proposals, workers were responsible for planning and executing their work. They were entrusted with production and were given the freedom to carry out their tasks in the way they believed was correct. The author describes it this way: managers and workshop leaders know better than anyone that their own knowledge and personal skills are far below the combined knowledge and skill of all the men under their command. Therefore, even managers with more experience leave their workers the problem of selecting the best and most economical way of doing the job. Hence, its principles seen in their historical perspective, represented a great advance and a new approach, a tremendous innovation in front of the system [22].

\section{The theory of the two factors of job satisfaction}

The theory of the two factors was formulated by Herzberg in the field of job satisfaction. According to this well-known theory, there are factors that determine job satisfaction and other very different factors that determine job dissatisfaction. The hygienic factors, production, dissatisfaction if its level is insufficient, but will not produce satisfaction if its level is sufficient. On the contrary, the growth factors will generate satisfaction when their level is sufficient, but they do not generate dissatisfaction when their level is insufficient. In this sense, satisfaction and dissatisfaction would not be polar opposites of the same continuum, as maintained by the traditional theory, according to which any factor can produce satisfaction or dissatisfaction depending on the level it reaches and the importance it has for each person, but there would be a double continuum in which the opposite of dissatisfaction would not be satisfaction, but the absence of dissatisfaction, and the opposite of satisfaction would not be dissatisfaction, but the absence of satisfaction (Table 4).

Table 4: Review of customer service theories.

\begin{tabular}{|c|c|c|}
\hline Theory & Author & Principles \\
\hline $\begin{array}{c}\text { Theory of the two factors of } \\
\text { the satisfaction in the job }\end{array}$ & $\begin{array}{c}\text { There are some factors that determine the job satisfaction and other factors very } \\
\text { different that determine the labor dissatisfaction (Herzberg, 1968, p. 103-106). The } \\
\text { hygienic factors, production, dissatisfaction if your level is insufficient, but they will not } \\
\text { produce satisfaction if their level is enough. On the contrary, growth factors will generate } \\
\text { satisfaction when your level is enough, but they do not generate dissatisfaction when } \\
\text { your level is insufficient Herzberg [19]. }\end{array}$ \\
\hline
\end{tabular}

Empirical Literature Review (Table 5) [23]

Table 5: Empirical review of the service literature and customer service.

\begin{tabular}{|c|c|c|c|c|}
\hline Authors (Year) & Research Title & Context & $\begin{array}{c}\text { Method or Instrument } \\
\text { Used }\end{array}$ & Result and Findings \\
\hline (Fonseca, 2008) [23] & $\begin{array}{l}\text { Improvement } \\
\text { proposal for the } \\
\text { customer service } \\
\text { of the Unipharm } \\
\text { group in Bogotá. }\end{array}$ & $\begin{array}{l}\text { It proposes the design of an } \\
\text { improvement proposal in the } \\
\text { customer service of the company } \\
\text { Grupo Unipharm Bogotá } \\
\text { based on a prior evaluation of } \\
\text { the same. This evaluation is } \\
\text { carried out in order to establish } \\
\text { satisfaction levels, the quality } \\
\text { of the service and the general } \\
\text { perception of the current clients } \\
\text { of the company. }\end{array}$ & $\begin{array}{l}\text { A semi-structured survey } \\
\text { whose purpose is to } \\
\text { measure the satisfaction } \\
\text { of the external client } \\
\text { by means of closed } \\
\text { questions that allow } \\
\text { to establish the needs } \\
\text { and expectations and } \\
\text { satisfaction indexes. }\end{array}$ & $\begin{array}{l}\text { The evaluation indicators related } \\
\text { to the attitudes of employees at a } \\
\text { general level are located at a good } \\
\text { level of satisfaction, however they } \\
\text { are perceived. Acceptable levels } \\
\text { in the availability and quality of } \\
\text { information. }\end{array}$ \\
\hline
\end{tabular}




\begin{tabular}{|c|c|c|c|c|}
\hline (Pinzón, 2015) [24] & $\begin{array}{l}\text { Quality of service } \\
\text { and value in } \\
\text { intermodal freight } \\
\text { transport. }\end{array}$ & $\begin{array}{l}\text { The service environment in } \\
\text { which this work focuses is } \\
\text { the logistics sector, and more } \\
\text { specifically freight transport } \\
\text { services. The interest in this } \\
\text { doctoral thesis for the study of } \\
\text { service variables in this specific } \\
\text { sector has its origin in the } \\
\text { same motivation from which } \\
\text { the PREVITRANS project arose, } \\
\text { project in which this research is } \\
\text { framed }\end{array}$ & $\begin{array}{l}\text { The questionnaire was } \\
\text { designed and elaborated. } \\
\text { First, a description of the } \\
\text { structure is presented of } \\
\text { the questionnaire that } \\
\text { allows to identify which } \\
\text { will be the main blocks. } \\
\text { Second, the authors } \\
\text { deepened the literature } \\
\text { review of measurement } \\
\text { scales and defined the } \\
\text { sets of specific indicators } \\
\text { for each of the constructs } \\
\text { that should be evaluated. }\end{array}$ & $\begin{array}{l}\text { The different approaches to } \\
\text { the academic study of both the } \\
\text { transport of goods by road and } \\
\text { the maritime. From a marketing } \\
\text { perspective, they converge in } \\
\text { the interest to explain how the } \\
\text { relationships between loader } \\
\text { companies and providers of } \\
\text { logistics services or specifically } \\
\text { transport work, emphasizing the } \\
\text { key elements that allow to succeed } \\
\text { in said relations. }\end{array}$ \\
\hline
\end{tabular}

\section{Contextual Framework}

Table 6: Food sector.

\begin{tabular}{|c|c|}
\hline Position & Business \\
\hline 1 & Grupo Bimbo \\
\hline 2 & Nestlé \\
\hline 3 & Grupo Herdez \\
\hline 4 & Kellogg's \\
\hline 5 & Bachoco \\
\hline 6 & La Costeña \\
\hline 7 & Gruma \\
\hline 8 & Mondélez \\
\hline 9 & Ferrero de México \\
\hline 10 & Grupo Bafar \\
\hline
\end{tabular}

The National Institute of Statistics and Geography [24] indicates the following within the framework of the presentation of the National Statistical Directory of Economic Units (DENUE), it announced that there are 4 million 9261,161 of companies in Mexico. These economic units represent 87 percent of all those reported in the 2014 INEGI Economic Census. The institute indicated that 2 million 825 thousand 272 companies were already registered in the previous version of the DENUE, while 2 million 100 thousand 789 of remaining businesses were incorporated in this version. On the other hand, of the 4 million 410 thousand 199 economic units that were registered in the Interactive DENUE 10/2013, a total of one million 584 thousand 927 businesses were closed, which closed or suspended activities. According to this report, the estimation, although preliminary, corresponds to an analysis of the general situation of all the companies, since the life expectancy of a business varies depending on the turn and its size. It is important to note that the report revealed that Mexican companies have an average life of 7.7 years, this according to INEGI estimates and their economic censuses taken every 5 years.

The new directory can be consulted through a mobile application, which shows all the information of the economic units registered on top of the geographic and demographic maps found on the agency's portal. Below is a graph in which it can be seen the life expectancy of companies in Mexico in its 100 main municipalities [25](Figure 2, Table 6-9). As shown above, the most important companies in Mexico in their different segments are listed.

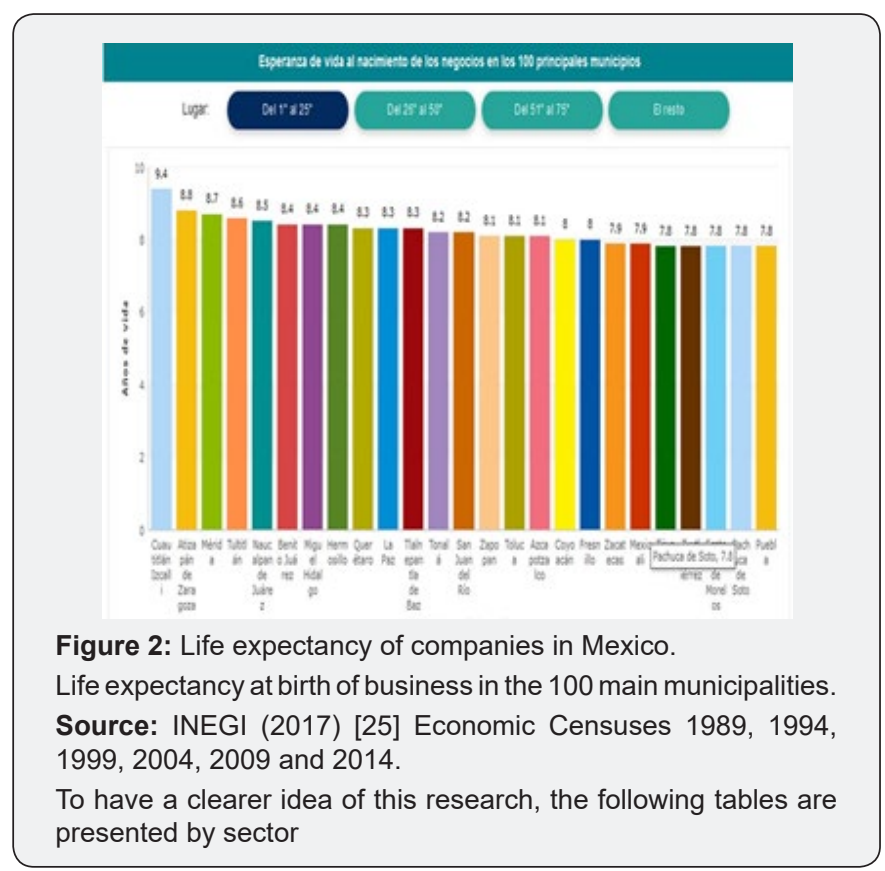

Table 7: Insurance sector.

\begin{tabular}{|c|c|}
\hline Position & Business \\
\hline 1 & Metlife \\
\hline 2 & Mapfre \\
\hline 3 & Allianz \\
\hline 4 & Axa \\
\hline 5 & Qualitas \\
\hline 6 & Zurich \\
\hline
\end{tabular}

Table 8: Automovil sector.

\begin{tabular}{|c|c|}
\hline Position & Business \\
\hline 1 & General Motors \\
\hline 2 & BMW \\
\hline 3 & Nissan \\
\hline 4 & Ford Motor Company \\
\hline 5 & Volkswagen \\
\hline 6 & Honda \\
\hline
\end{tabular}




\begin{tabular}{|c|c|}
\hline 7 & Toyota \\
\hline 8 & FCA \\
\hline 9 & Mercedes Benz \\
\hline 10 & Mazda \\
\hline
\end{tabular}

Table 9: Autoservices and departmental services

\begin{tabular}{|c|c|}
\hline Position & Business \\
\hline 1 & Liverpool \\
\hline 2 & Walmart \\
\hline 3 & Marti \\
\hline 4 & Comercial Mexicana \\
\hline 5 & Soriana \\
\hline 6 & Coppel \\
\hline 7 & Chedrahui \\
\hline 8 & Grupo Famsa \\
\hline 9 & Costco \\
\hline
\end{tabular}

\section{Research Method}

\section{Kind of investigation}

This research is analytical and descriptive, because it contains the main concepts about the research, as well as the main authors and creators of the same. It is descriptive because in the research there are tables that help to explain in a certain simpler way for the correct compression and differentiation of these concepts.

Table 10: Description of the variables, dimensions, indicators, instrument operationalization of variables and statistical analysis of research (Table 1-10 from own elaboration).

\begin{tabular}{|c|c|c|c|c|c|c|}
\hline Variables & Description & Dimensions & Indicators & Instrument & $\begin{array}{c}\text { Operationalization } \\
\text { of Variables }\end{array}$ & $\begin{array}{c}\text { Statistical } \\
\text { Analysis }\end{array}$ \\
\hline \multirow{5}{*}{ X0 } & \multirow{5}{*}{$\begin{array}{l}\text { That activity of } \\
\text { interrelation offered } \\
\text { by a supplier with the } \\
\text { purpose that a client get } \\
\text { a product or service, both } \\
\text { at the time and in the } \\
\text { precise place and where } \\
\text { it is ensured a correct use } \\
\text { of it (Agudelo, 2013, p. } \\
\text { 17-22) [4] }\end{array}$} & Company & $\begin{array}{l}\text { Customer } \\
\text { retention }\end{array}$ & \multirow{5}{*}{$\begin{array}{c}\text { Descriptive } \\
\text { bibliographical } \\
\text { analysis }\end{array}$} & \multirow{5}{*}{$\begin{array}{l}\text { Information is } \\
\text { collected from } \\
\text { expert authors, } \\
\text { internationally } \\
\text { recognized. To } \\
\text { contrast with the } \\
\text { variable. }\end{array}$} & Tables \\
\hline & & Client & Buyer satisfaction & & & \multirow{4}{*}{ Bar graphs } \\
\hline & & \multirow[b]{3}{*}{ Survive attitude } & Customer loyalty & & & \\
\hline & & & Customer rating & & & \\
\hline & & & Accessible simple & & & \\
\hline
\end{tabular}

\section{Contrasting of hypothesis}

This research corroborates what Hair [7] mentions that a service is the result of the application of human or mechanical efforts to people or objects. Services refer to a fact, performance or effort that is not physically possible. Being in this way that the service can be manipulated by the attention that a human being uses on the service rendered, giving it a "plus" making the service better than it already is, or simply improving it.

\section{Findings}

The findings of this research are that you can verify that there is a noticeable difference between the variables, and with this that employers can understand the difference of these two

\section{Design of the investigation}

Description of the variables, dimensions, indicators, instrument operationalization of variables and statistical analysis of research (Table 10).

\section{Analysis of data}

This research is analytical and descriptive, because it contains the main concepts about research, as well as the main authors and creators of the same. It is descriptive because in the research there are tables that they help to explain in a simpler and simple way for their correct and easy understanding of these concepts, as well as the differentiation between them.

\section{Analysis of Results}

\section{Testing hypothesis and results}

The hypothesis of this research is that customer service has an impact or direct relationship with customer care. At first glance, it could be said that the definition of both concepts is similar, but in this research, it shows that this is not the case, since there is a small difference between these concepts. The main difference is that many times a service is provided by a system or a company, and attention is given by a human being, and when these are combined in an appropriate manner, the hypothesis of this work is verified, that customer service has an impact on customer care. important concepts, so they can apply them correctly to obtain customer loyalty, since it is easier to retain a client than to attract a new one.

\section{Contributions}

This research provides small and medium entrepreneurs with knowledge of vital importance for their organizations, since this work understands the importance and difference between a service and attention, and once understood that can better train their staff to obtain better results in their companies.

\section{Implications}

This research is mainly aimed at small and medium-sized Mexican entrepreneurs. These are abundant in Mexico because 
they do not care much if their clients are satisfied with the services and attention provided by their part of their staff, and with this research it can be understood the importance and the difference that exists between both.

\section{Conclusions and Recommendations}

Within this research it is important to point out that the personnel of each company must be prepared and psychologically trained to be able to perform the position in which they are working, since with that they will be able to perform their work better. Consequently, the employee unconsciously gives a good service, followed by good customer care, since today's companies must pay more attention to how they provide their services, using the marketing techniques and strategies necessary to implement these changes. In addition to that, the business competitiveness of today is very big. That is why these entrepreneurs must implement new strategies, starting with better training their staff, and investing in marketing strategies that exist some very economic, such as having a presence on social networks, or have certain promotions to better retain their customers. The recommendations of this research are that some service companies do not give due importance to the difference between both variables, and it should be noted that they take it as if they were the same, which was found in this research that there is a difference.

\section{References}

1. Reyes GE (2010) Proposal of a financial model for sustainable corporate growth. Finance and Economic Policy 2(2): 2-8.

2. Godoy JN (2011) Human capital in customer service and quality in the service. Observatorio Laboral Revista Venezolana 4(4): 23-35.

3. González B (2010) Service strategies: elements for business success. Multiciencias 2(3): 2-5.

4. Agudelo MR (2013) The CRM as a tool for customer service in the organization. Vision of the future 17(1): 130-151.

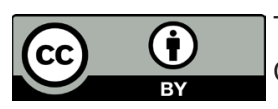

This work is licensed under Creative

Commons Attribution 4.0 License
5. Stanton WE (2006) Fundamentals of Marketing. Painesville McGrawHill, United States.

6. Sandhusen R (2002) Marketing. Spain Continental.

7. Hair JM (2002) Marketing. Londres International Thomson, UK.

8. Association AM (2006) Dictionary of Marketing Terms.

9. Kotler PB (2004) The marketing of professional services. Chicago: Paidós SAICF.

10. Marketing TC (2009) cim.com.uk.

11. Marketing TC (1999) Marketing Dictionary. Madrid Cultural SA.

12. Barquero JD (2007) Customer Marketing. Barcelona McGraw-Hill, United States.

13. Kotler P (2003) The 80 Essential Marketing Concepts from A to Z. Chicago: Pearson Education.

14. Inches G (1983) Creative Customer Service Management. Spain International Journal of Physical Distribution.

15. Herrera J P (2005) Services. Economics classroom 2(3): 2-6.

16. Kahmeman D (1973) The attention Princeton University, US.

17. Prieto AB (2001) Customer Support. Spain Piramide.

18. Prieto AB (2007) Customer service. Spain Piramide.

19. Herzberg F (1968) Theories of the Administration.

20. Fayol H (1976) Industrial and general administration. Mexico Herrero Hermano Sucs SA.

21. Gregor Mc (1960) The human Side of Enterprise Management Review. American Management Association 22(11): 22-28.

22. Taylor F (1973) Principles of Administration. Buenos Aires Atheneum.

23. Fonseca OB (2008) Improvement proposal for the customer service of the Unipharm Bogotá group. University of La Salle, US.

24. Pinzón S (2015) Quality of service and value in the intermodal transport of maracas. Vniversitat De Valéncia INEGI 5 million companies in Mexico, Mexico.

25. INEGI (2017) National Institute of Economics and Geography and Informatics. Mexico.

\section{Your next submission with Juniper Publishers will reach you the below assets}

- Quality Editorial service

- Swift Peer Review

- Reprints availability

- E-prints Service

- Manuscript Podcast for convenient understanding

- Global attainment for your research

- Manuscript accessibility in different formats

( Pdf, E-pub, Full Text, Audio)

- Unceasing customer service

Track the below URL for one-step submission

https://juniperpublishers.com/online-submission.php 